\title{
Infectious bursal disease virus in poultry: current status and future prospects
}

This article was published in the following Dove Press journal:

Veterinary Medicine: Research and Reports

19 January 2016

Number of times this article has been viewed

\author{
Tamiru Negash Alkie' \\ Silke Rautenschlein ${ }^{2}$ \\ 'Department of Pathobiology, Ontario \\ Veterinary College, University of \\ Guelph, Guelph, Canada; ${ }^{2} \mathrm{Clinic}$ for \\ Poultry, University of Veterinary \\ Medicine Hannover, Hannover, \\ Germany
}

\begin{abstract}
Infectious bursal disease virus (IBDV) affects immature B lymphocytes of the bursa of Fabricius and may cause significant immunosuppression. It continues to be a leading cause of economic losses in the poultry industry. IBDV, having a segmented double-stranded RNA genome, is prone to genetic variation. Therefore, IBDV isolates with different genotypic and phenotypic diversity exist. Understanding these features of the virus and the mechanisms of protective immunity elicited thereof is necessary for developing vaccines with improved efficacy. In this review, we highlighted the pattern of virus evolution and new developments in prophylactic strategies, mainly the development of new generation vaccines, which will continue to be of interest for research as well as field application in the future.
\end{abstract}

Keywords: epidemiology, IBDV, immunity, poultry, vaccine

\section{Introduction}

In all poultry producing regions of the world, infectious bursal disease virus (IBDV) continues to be a major constraint for poultry farmers. The consequences of immunosuppression associated with IBDV are vaccination failure and susceptibility of chickens to opportunistic pathogens. It was also shown that IBDV-infected birds may become a good propagator for other viral pathogens. For example, low pathogenic duck adapted avian influenza virus becomes more virulent when serially passaged in IBDV-infected chickens. ${ }^{1}$ Moreover, highly virulent IBDV can cause high mortality in unprotected flocks.

IBDV is a double-stranded RNA (dsRNA) virus, ${ }^{2}$ which targets immature B lymphocytes of the bursa of Fabricius (BF), a primary lymphoid organ in avian species, and subsequently causes B-cell depletion in bursal follicles. Macrophages may be susceptible to IBDV (reviewed by Khatri and Sharma ${ }^{3}$ ) and recently IBDV-positive T-cell populations were detected in the BF. ${ }^{4}$ Efficient horizontal virus transmission between flocks through ingestion of feed and water contaminated with infectious feces is remarkable, once a rearing site has been contaminated. However, there are no indications of vertical transmission.

The virus may use one or more putative host cell receptors/structures such as $\mathrm{N}$-glycosylated polypeptide(s), ${ }^{5}$ heat shock proteins (HSPs), ${ }^{6} \alpha 4 \beta 1$ integrin, ${ }^{7}$ or lipid raft endocytic pathways ${ }^{8}$ to enter into permissive cells. Mononuclear phagocytic cells and lymphoid cells of the gut mucosa may serve as targets for initial IBDV infection and replication following oral exposure. Infected macrophages transport the virus to the $\mathrm{BF}$, where extensive replication takes place. ${ }^{9}$ Virus spread from the bursa to other lymphoid organs may occur depending on the virulence of the infecting IBDV strain.
Correspondence: Silke Rautenschlein

Clinic for Poultry, University of Veterinary Medicine Hannover, Bünteweg 17, 30559

Hannover, Germany

Tel 49 5II 9538779

Email silke.rautenschlein@tiho-hannover.de
Veterinary Medicine: Research and Reports 2016:7 9-18 (c) (i) (2) 2016 Alkie and Rautenschlein. This work is published and licensed by Dove Medical Press Limited. The full terms of this license are available at https://www.dovepress. com/terms.php and incorporate the Creative Commons Attribution - Non Commercial (unported, v3.0) License (http://creativecommons.org/licenses/by-nc/3.0/). By accessing Press Limited, provided the work is properly attributed. For permission for commercial use of this work, please see paragraphs 4.2 and 5 of our Terms (https://www.dovepress.com/terms.php). 
Since the first discovery of classical IBDV strains in the USA over 50 years ago, ${ }^{10}$ the virus has spread throughout the world and complex evolution of the virus has taken place. Our understanding of IBDV epidemiology has been much more comprehensive by today. All major poultry producing regions report the coexistence of two or more strains of variable pathogenicity. ${ }^{11} \mathrm{~A}$ recent study addressing the global molecular epidemiology of IBDV from four continents revealed that $60 \%-76 \%$ of IBDV isolates are very virulent (vv) IBDV strains. However, other strains including variants are also gaining grounds and are the most prevailing in the USA.

Besides biosecurity, vaccination is the most important measure to control IBDV in the field. Classical and variant strains have been used for many years, but extensive usage of live vaccines in the field is thought to favor the emergence of new strains. The emerging viruses evade vaccine-induced immunity, and may in addition contribute their viral genome to reassortment and recombination events. In addition, some IBDV live vaccines are expected to maintain quasispecies nature, which in the face of selection pressure may favor the outgrowth of more virulent antigenic variants or mutants in the viral population. ${ }^{12}$ Understanding the current epidemiology of IBDV and the implementation of new prophylactic measures are vital to control IBDV. This review article bridges the current understanding of IBDV from epidemiological and immunological perspectives, to possible control measures and new developments in prophylactic strategies against IBDV.

\section{IBDV genome}

IBDV has a bisegmented dsRNA genome. ${ }^{2}$ Segment A contains two partially overlapping open reading frames (ORFs). The larger ORF encodes for a polyprotein (PP), which is autocatalytically cleaved into the two structural proteins, virus protein (VP)2 and VP3, and a serine (S) protease, VP4. ${ }^{13}$ The PP is considered as the main mediator of IBDV-induced immunosuppression and pathogenicity. ${ }^{14} \mathrm{VP} 2$ contains the major antigenic sites responsible for induction of neutralizing antibodies (Abs). ${ }^{15} \mathrm{VP} 5$, which is encoded by the small ORF, is involved in the dissemination of the virus from infected cells. ${ }^{16}$

The crystal structure of VP2 indicates that most amino acid (aa) changes are localized in the exposed projection domain that contains the hypervariable region (hVP2). ${ }^{17}$ hVP2 has two major hydrophilic domains namely major hydrophilic peak A (aa 212-224) and peak B (aa 314-325) ${ }^{18}$ that form loop $\mathrm{P}_{\mathrm{BC}}\left(\right.$ aa 219-224) and $\mathrm{P}_{\mathrm{HI}}$ (aa 316-324), ${ }^{19,20}$ respectively. The minor hydrophilic peak 1 (aa 248-254) and peak 2 (aa 279-290) of hVP2 form loop $\mathrm{P}_{\mathrm{DE}}$ (aa 249-254) and $\mathrm{P}_{\mathrm{FG}}$ (aa 279-284), respectively. ${ }^{19}$

Segment B-encoded polymerase (VP1) mediates viral RNA replication. ${ }^{21}$ The VP1 crystal structure shows three domains: the N-terminal (aa 1-167), central polymerase (aa 168-658), and C-terminal (aa 659-878) regions. ${ }^{22}$

\section{IBDV is constantly evolving in the field with varying virulence}

Historically, IBDV evolution has three major events: the first description of a classical IBDV outbreak in 1957 and the occurrence of antigenic variants in 1980s, both in the USA as well as the detection of vvIBDV in late 1980s in Europe. ${ }^{10,23}$ While classical and variant strains dominated field outbreaks for nearly 5 decades in the USA, the first IBDV outbreak related to VVIBDV in the USA was reported in 2008. ${ }^{24}$ IBDV-neutralizing Ab escape mutants that have been reported in most recurrent outbreaks in vaccinated flocks were the result of mutations at major hydrophilic peak $\mathrm{A}$ and $\mathrm{B}$ domains (loop $\mathrm{P}_{\mathrm{BC}}$ and $\mathrm{P}_{\mathrm{HI}}$ ) of hVP2. ${ }^{25,26}$ Moreover, the emergence of reassortant field strains plays a significant role in current IBDV evolution.

In recent years, IBDV field strains from different continents showed aa exchanges at minor hydrophilic peak domains (loop $\mathrm{P}_{\mathrm{DE}}$ and $\mathrm{P}_{\mathrm{FG}}$ ) of hVP2. ${ }^{27-29}$ Single or combined mutations at these regions affect the virulence of IBDV field isolates. Experimentally, the substitution of aa at positions 253 (Q253H), 279 (D279N), and 284 (A284T) in the VP2 of vvIBDV isolates resulted in loss of virulence. ${ }^{30}$ However, a single aa mutation at position $253(\mathrm{H} 253 \mathrm{Q} / \mathrm{N})$ or 249 (R249Q) in VP2 markedly increased the virulence of an attenuated IBDV strain. ${ }^{31}$ In addition, mutation at position $212(\mathrm{D} 212 \mathrm{~N})$ is common in most recent vvIBDV isolates and may influence the structure of VP2 and consequently the antigenicity of the virus. ${ }^{32}$ Moreover, a $S$ residue instead of glycine $(\mathrm{G})$ at position 254 (loop $\mathrm{P}_{\mathrm{DE}}$ ) was reported from vvIBDV field isolates detected from chickens vaccinated with classical IBDV vaccines, ${ }^{33}$ suggesting a role of this aa mutation in vaccination failure. ${ }^{28}$ Chickens vaccinated with a live Delaware (Del-E) variant and challenged with a neutralizing $\mathrm{Ab}$ escape Del-E mutant that contains $\mathrm{S}$ at position 254 developed severe bursal lesions. ${ }^{28}$

In the USA, one-third out of 300 IBDV field isolates failed to react with any of the known monoclonal Abs raised against VP2, which were used to identify IBDV strains for the last 2 decades and hence demonstrate enormous virus evolution. ${ }^{27}$ IBDV field isolates bearing VP2-epitopes chimeric of at least 
three strains are reported, which contribute to an enormous variation in antigenicity and virulence diversity. ${ }^{34}$ Frequent mutations in VP2 indicate that certain codons are under constant purifying selection pressure and point mutations (antigenic drift) may favor emerging neutralizing Ab escape mutants. $^{35}$

\section{IBDV ecological diversity and phylogenetic clustering}

Based on geographic origin, phylogenetic analysis using either partial or complete VP2 nucleotide sequences clustered vvIBDV strains in one well-defined major monophyletic lineage. ${ }^{36,37}$ In contrast to these reports, recent vvIBDV isolates from major chicken producing regions of People's Republic of China showed rather divergent VP2 phylogenetic clusters. When compared with earlier Chinese vvIBDVs, the present Chinese vvIBDVs have unique mutations in both segments and are more virulent compared with the typical European vvIBDV, despite similarity in antigenic features. ${ }^{38}$ In support of a direct correlation between geographic origin of IBDV and phylogenetic clusters, Jackwood and Stoute ${ }^{39}$ described spatially restricted IBDVs in northeast Ohio that contain mutations unique to this geographic region in both VP2 and VP1 gene. On the contrary, a large number of sequences obtained from VP2 of IBDV field isolates from the USA were phylogenetically different from any known IBDV VP2 sequences. ${ }^{27}$ The VP1 gene of most IBDV strains, however, shows multiple phylogenetic lineages providing evidence of VP1 contribution in IBDV epidemiology. ${ }^{37,40}$ All these reports highlight the continuing evolution of both segments of the virus and the circulation of genetically diverse IBDVs.

In addition, the existence of a worldwide-spread genetic lineage of IBDVs designated as distinct IBDVs has been described, which cause only immunosuppression. ${ }^{41}$ A discriminant analysis of principal components, a novel specific multivariate method that identifies clustering patterns of IBDVs, grouped distinct IBDVs as a distinct cluster of genetically related viruses separated from the other typical IBDV strains. Genetic distance estimation predicts that these viruses are one of the most genetically divergent IBDV and showed the highest between-group variance and genetic distance from vvIBDVs.

\section{Recombination events in IBDV}

Sequence diversity among field IBDVs may also be due to homologous recombination between VP2 genes. IBDV isolates were identified which gained aa sequences from classic IBDV within the $\mathrm{P}_{\mathrm{BC}}$ and $\mathrm{P}_{\mathrm{HI}}$ loops and sequences from Del-E variant strains within the minor $\mathrm{P}_{\mathrm{DE}}$ and $\mathrm{P}_{\mathrm{FG}}$ loops. ${ }^{34}$ Other isolates were described to have undergone intrasegment recombination in their segment $\mathrm{B}$ between two vvIBDV donors. ${ }^{42}$ If the exposed capsid residues $(253 \mathrm{H}$ and $284 \mathrm{~T}$ ), which are involved in particle-particle interaction are affected by recombination events, the orientation of the capsid domains may be modified and vaccine failure may be observed. ${ }^{43}$

\section{Genetic reassortments play a significant role in IBDV epidemiology}

Basically, reassortment contributes to the first emergence of vvIBDV in the late 1980s in Europe..$^{23,44}$ Prediction of the most recent common ancestor of vvIBDV describes an approximate most recent common ancestor of vvVP2 around 1960 and of VvVP1 from an unidentified avian reservoir around 1980 indicating that these two proteins of vvIBDV have evolved at different time points. ${ }^{44,45}$ Recent genetic analysis showed that most reassortant IBDVs reported from around the world have segment A from vvIBDV that maintain key virulence marker aa in their VP2 (222A, 256I, 294I, and 299S, ${ }^{46,47}$ attenuated strains have $253 \mathrm{H}$ and 284T, and 253Q and 284A are often found in variant strains ${ }^{33}$ ) and segment $\mathrm{B}$ from attenuated vaccine strains. ${ }^{45,48}$ Reassortants with segments from serotype 1 and serotype 2 IBDV or segment $A$ from an attenuated and segment B from vvIBDVs have also been reported..$^{49}$ Different genotypes of IBDV are sometimes isolated from the same bursa implying coinfection being common in the field. ${ }^{50}$

The frequent isolation of reassortant IBDV field isolates indicates that phylogenetic markers need to include VP1 in the molecular epidemiology of IBDV, especially if considering the contribution of VP1 to IBDV virulence. ${ }^{51-53} \mathrm{~A}$ field reassortant IBDV comprising segment A of VvIBDV and segment B of an attenuated strain caused reduced mortality in specific pathogen free (SPF) chickens compared with a typical vvIBDV isolate. ${ }^{54}$ When regions of VP1 of a vvIBDV strain were exchanged with VP1 counterparts of an attenuated IBDV, the resulting recombinant virus showed reduced virulence and bursal lesions in chickens. ${ }^{55}$ Recent studies have identified putative virulence markers in VP1 of IBDV field isolates. ${ }^{56} \mathrm{~A}$ TDN (threonine/aspartic acid/asparagine) motif was identified at aa residues 145,146 , and 147 of all vvIBDVs tested, which is absent in most non-vvIBDV isolates. ${ }^{57}$ Replacement of the TDN motif of a vvIBDV strain with TEG (threonine/glutamic acid/glycine) or NEG (asparagine/glutamic acid/glycine) resulted in loss of virulence, and the change of NEG to TDN increased the virulence for an attenuated strain, indicating the contribution of these three 
aa to the polymerase activity. ${ }^{58} \mathrm{Yu}$ et al ${ }^{59}$ further evaluated the pathogenicity of a VVIBDV strain by exchanging a single aa at VP1 position 4 (V4I) which resulted in attenuation of the respective mutated virus.

\section{Host immunity to IBDV: innate and adaptive immune responses Role of pattern recognition receptors in the immune response to IBDV}

The innate immune response is the first-line of defense against pathogens in vertebrate species. This response is mediated by pattern recognition receptors (PRRs), which detect pathogenassociated molecular patterns (PAMPs) for induction of effector molecules. ${ }^{60}$ In chickens, ten different Toll-like receptors (TLRs), a well-characterized member of PRRs, have been identified and their natural or synthetic ligands representing PAMPs have been characterized. ${ }^{61}$ Chickens mucosally infected with IBDV showed upregulation of TLR transcripts including TLR3 $3^{62,63}$ and TLR2 $1^{62}$ and molecules associated with TLRs such as MD-1 and MD- $2^{64}$ in the BF during the acute phase of virus replication. Other studies have reported the differential regulation of TLR3 and TLR7 after mucosal IBDV infection. ${ }^{62,65}$ The results of these studies suggest that TLRs may be involved in IBDV recognition for initiation of innate immunity. The chicken melanoma differentiation-associated gene (MDA5) has also been suggested as intracellular PRRs for IBDV. ${ }^{66}$ In the course of mucosal IBDV infection, Smith et $\mathrm{al}^{62}$ revealed increased expression of MDA5 in the BF during early stages of IBDV infection.

\section{Expression of innate response genes} during in vitro and in vivo IBDV infection

When administered per os, IBDV can be detected at 8-12 hours post infection in intestinal mononuclear phagocytic cells, which transport the virus to the BF for extensive replication in B-cells. IBDV infection activates intracellular signaling cascades such as the nuclear factor (NF)- $\kappa \mathrm{B}$ pathway. ${ }^{67}$ Increased macrophage infiltration into the BF may cause higher expression of proinflammatory cytokines (interleukin [IL]-6, IL-1 $\beta$, and IL-18) and inducible nitric oxide synthase. ${ }^{63,68}$ Higher expression of interferon (IFN)- $\gamma$ and chemokines (CXCLi2) was detected in the BF compared with spleen specimens. ${ }^{69}$ Further IBDV infection studies in newly hatched chickens or late-stage chicken embryos (infected at embryonation day 18) resulted in higher expression of other components of innate immunity such as stress response proteins, complement components, and $\beta$-defensins in primary lymphoid organs. ${ }^{64,70}$
Transcriptome analyses may help to identify other candidate host genes involved in the development of clinical disease, bursal lesions, and protection. ${ }^{63}$

Rauf et $\mathrm{al}^{71}$ and Sharma and Lee ${ }^{72}$ did not find significant evidence of natural killer (NK)-cell involvement in the early immune response after IBDV infection. Smith et al ${ }^{62}$ demonstrated higher expression of NK lysin to approximately 15 -fold at 4 days post infection (dpi) compared with virus-free controls suggesting cytotoxic T-cells and NK cells involvement. Still, the role of NK cells in IBDV pathogenesis or immunity is not fully understood.

\section{Type I IFN responses during IBDV infection}

IBDV infection leads to upregulation of antiviral response genes such as type I IFNs in the BF at 3 dpi and the expression of IFN-stimulated genes such as viperin, $\mathrm{Mx}$, and chicken ZAP in BF and spleen tissues. ${ }^{63,73,74}$ This was confirmed in other studies, ${ }^{64}$ where genes with regulatory functions (IFN regulatory factor 7) and janus kinases/signal transducer and activators of transcription (JAK/STAT), as well as other classes of IFN-stimulated genes including interferon induced protein with tetratricopeptide repeats 5 , IFN-induced transmembrane protein (IFITM) 1, IFITM3, IFITM5, 2'-5'-oligoadenylate synthase, and dsRNA-dependent protein kinase were induced following IBDV infection. ${ }^{62,64}$ Recent studies indicated that suppression of the IFN response may promote IBDV replication, supporting the role of IFN in IBDV control and pathogenesis. ${ }^{75}$ Understanding innate immune mechanisms will benefit the development of strategies to target the antiviral pathways in the chicken to control IBDV.

\section{Adaptive immune responses and mechanisms to prevent IBDV infection}

IBDV evades innate responses by interfering with the IFN pathway ${ }^{76}$ or impairment of dendritic cell function. ${ }^{77}$ For further control of infections, chicken rely on adaptive immunity. Virus neutralizing Abs against the conformation dependent neutralizing epitopes can be detected after few days of infection or vaccination and provide protection against antigenetically related viruses. ${ }^{15,78}$ The roles of T-cell subpopulations in IBDV protection were previously described (reviewed by Mahgoub et $\mathrm{al}^{4}$ ).

The status of IBDV vaccines has been recently reviewed by Müller et al. ${ }^{79}$ Here, we have summarized commercial and alternative vaccine candidates and their mechanisms of protection against IBDV (Table 1). Conventional live attenuated IBDV vaccines categorized as mild, intermediate, or intermediate plus are suitable for mass vaccination and 
Table I Examples of experimental candidate and commercial new generation IBDV vaccines

\begin{tabular}{|c|c|c|c|}
\hline Vaccine types & Target antigen or gene & $\begin{array}{l}\text { Expression systems } \\
\text { or vectors }\end{array}$ & Parameters evaluated and references \\
\hline \multirow[t]{4}{*}{ Subunit } & Hypervariable region of VP2 & Pichia pastoris & $70 \%$ protection against challenge $e^{122}$ \\
\hline & N-terminal VP2 (aa 18-139) & Escherichia coli & $\uparrow$ ELISA titer, $100 \%$ protection against mortality ${ }^{123}$ \\
\hline & Mimotope & E. coli & $\begin{array}{l}\uparrow \text { ELISA and VN Ab titer, } 100 \% \text { protection against } \\
\text { mortality } 124\end{array}$ \\
\hline & VP2 & Plants & Seroconverted, $80 \%$ protection against mortality ${ }^{125,126}$ \\
\hline \multirow[t]{2}{*}{$\begin{array}{l}\text { Chimeric virus-like } \\
\text { particles }\end{array}$} & $\begin{array}{l}\text { Neutralizing epitope from } \\
\text { the } P_{B C} \text { loop of VP2 }\end{array}$ & Bamboo mosaic virus & $\begin{array}{l}\uparrow \text { ELISA titer, mild-to-moderate bursal lesions } \\
\text { after challenge }\end{array}$ \\
\hline & $\begin{array}{l}\text { VP2 and } N \text {-terminus M2 } \\
\text { extracellular domain of } \mathrm{H} 9 \text { AIV }\end{array}$ & Baculovirus vector & $\begin{array}{l}\uparrow \text { ELISA titer and VN Ab titer, improved protection } \\
\text { against challenge }{ }^{128}\end{array}$ \\
\hline Chimeric proteins & Mimotope polypeptide & Human hepatitis B virus & $\begin{array}{l}\uparrow \text { ELISA and VN Ab titer, } 100 \% \text { protection against } \\
\text { mortality }{ }^{129}\end{array}$ \\
\hline \multirow[t]{7}{*}{ Viral vectored } & VP2 & Fowlpox virus & $\begin{array}{l}14 \% \text { and } 33 \% \text { of the chickens protected against } \\
\text { gross and histological lesions, respectively }{ }^{130}\end{array}$ \\
\hline & & Marek's disease virus & $\begin{array}{l}55 \% \text { protection against bursal lesions, no sterile } \\
\text { immunity }{ }^{\prime 1}\end{array}$ \\
\hline & & Semliki forest virus & Induction of $\mathrm{VN} A b^{132}$ \\
\hline & & Vaccinia virus & Induction of $\mathrm{VN} A b^{133}$ \\
\hline & & Avian adenovirus & $\uparrow$ VN Ab titer, mortality up to $20 \%$ after challenge ${ }^{134}$ \\
\hline & & T4 bacteriophage & $\uparrow$ ELISA titer, no clinical signs or death $h^{135}$ \\
\hline & & Canarypox & Induction of VN Abs ${ }^{136}$ \\
\hline \multirow[t]{2}{*}{ Bacterial delivery } & VP2 & E. coli & Seroconversion, $95 \%$ protection against mortality ${ }^{106}$ \\
\hline & PP & Salmonella Typhimurium & $73 \%$ protection against mortality and seroconversion ${ }^{107}$ \\
\hline \multirow[t]{3}{*}{ DNA vaccine } & $\begin{array}{l}\text { Immunodominant VP2 gene } \\
\text { fragment }\left(V P 2_{52-417}\right)\end{array}$ & E. coli & $\begin{array}{l}75 \% \text { protection against bursal lesions, } 90 \% \text { survival, } \\
\uparrow \text { IgY and splenocyte proliferation }{ }^{137}\end{array}$ \\
\hline & $\begin{array}{l}\text { VP2 and HSP70 (fused and } \\
\text { expressed in one plasmid), } \\
\text { recombinant VP2 }\end{array}$ & $\begin{array}{l}\text { Saccharomyces cerevisiae } \\
\text { (DNA prime-protein boost) }\end{array}$ & $\begin{array}{l}\text { I00\% protection against mortality, } \uparrow \text { ELISA Ab and } \\
\text { cell proliferation, } \uparrow \text { expression of IFN- } \gamma \text { and IL- I } 2 \text {, } \\
\text { IL- } 10^{99}\end{array}$ \\
\hline & $\begin{array}{l}\text { PP and chicken IL-I8 } \\
\text { (cloned in one plasmid) }\end{array}$ & E. coli & $\begin{array}{l}\text { 93\% protection, } \uparrow \text { ELISA Ab and cell proliferation } \\
\text { and } \uparrow \text { induction of IFN- } \gamma \text { and IL-4 } 4^{93}\end{array}$ \\
\hline DNA/protein vaccine & VP2 & VP2 DNA (E. coli) and rVP2 & $\begin{array}{l}\text { I00\% protection against vvIBDV-induced mortality, } \\
\uparrow \text { ELISA, and VN Ab, } \uparrow \text { lymphocyte proliferation, } \\
\uparrow \text { induction of IL- } 4 \text { and IFN- } \gamma^{138}\end{array}$ \\
\hline
\end{tabular}

Note: Most of the vaccines evaluated in these studies were administered to chickens of different ages by parenteral vaccination (intramuscular and subcutaneous), with exception of the ones delivered by bacterial vectors or plants.

Abbreviations: aa, amino acid; Ab, antibody; AIV, avian influenza virus; ELISA, enzyme-linked immunosorbent assay; HSP, heat shock protein; IBDV, infectious bursal disease virus; IFN, interferon; IL, interleukin; PP, polyprotein; VN, virus neutralizing; VP, virus protein; vv, very virulent; $\uparrow$ upregulation or increased.

when applied in drinking water can induce robust immunity ${ }^{80}$ The potential for reversion to virulence, ${ }^{81}$ residual immunosuppressive effects, ${ }^{82}$ as well as their role as genetic sources for the generation of reassortant new viruses ${ }^{32}$ are major safety concerns. Killed vaccines for breeder vaccination to transfer maternal Abs to progeny ${ }^{83}$ and infectious bursal disease (IBD)-immune complex vaccines developed for in ovo (administered at embryonation day 18$)^{84}$ as well as posthatch vaccination of broilers ${ }^{85}$ have been used in the past. IBD-immune complex vaccines are prepared by combining certain quantity of IBDV-specific hyperimmune sera with live intermediate plus IBDV. ${ }^{86}$

As the viral capsid protein, VP2 carries immunodominant epitopes responsible for the induction of a protective humoral immune response..$^{15}$ The PP gene as a whole, the mature VP2, or immunogenic/neutralizing domains of VP2 are targeted to produce new generation candidate vaccines. Viral-vectored vaccines such as the herpesvirus of turkeys-IBD vaccine were licensed for in ovo and posthatch vaccination of broilers and layers in various countries. ${ }^{87,88}$ These vectored vaccines induce strong systemic neutralizing and/or mucosal Abs. Limitations are possible interference with other herpesvirus of turkeys vaccines given at the same time, which may affect vaccine efficacy by reducing their replication in host tissues. IBDV DNA vaccines may elicit cell-mediated immunity including memory T-cell responses, ${ }^{89,90}$ contributing to the protective efficacy of the vaccine. IBDV-VP2 subunit vaccines produced in yeast and Escherichia coli expression systems have been licensed for commercial use. ${ }^{91,92}$ 


\section{The way forward: improving the quality of vaccine-induced immune responses by molecular adjuvants and vaccine delivery systems New generation vaccine adjuvants}

Due to partial protection offered by vaccination, especially by nonreplicating constructs (subunit and DNA vaccines), the development of new adjuvants and adjuvant formulations may help to improve the immunogenicity and protection provided by these vaccines. Vaccination of chickens with a DNA vaccine coexpressing VP2/4/3 and IL-18 led to protection against challenge compared with the DNA vaccine expressing only VP2/4/3. ${ }^{93}$ Good indicators of strong cellmediated immunity were higher T-cell counts and higher antigen-specific T-cell proliferation in the cytokine-adjuvant group. The immune potentiating effect of IL-2 was found to be significant when cloned together with the VP2 gene into a bicistronic eukaryotic expression vector. ${ }^{94}$ Recombinant chicken cytokines such as IL-12 were used to improve vectored IBD vaccines. ${ }^{95}$ But not in all cases tested recombinant cytokines improved the IBDV vaccine response significantly as shown with recombinant IFNs and IL- $1 \beta$ in combination with an inactivated IBD vaccine. ${ }^{96}$

The administration regime of adjuvants may modify their efficacy as shown by Negash et al, ${ }^{97}$ who demonstrated that adjuvant application at staggered intervals improved vaccine efficacy compared with simultaneous application of vaccine and adjuvant. Other adjuvant candidates have also been experimentally tested, including porcine lactoferrin, ${ }^{98} \mathrm{HSPs},{ }^{99}$ chicken beta-defensin- $1,{ }^{100}$ or synthetic PAMP mimics such as $\mathrm{CpG}$ oligodeoxynucleotides ${ }^{97,101,102}$ in combination with different vaccine types. A DNA vaccine encoding the C-terminal domain of the HSP70 of Mycobacterium tuberculosis genetically fused with the full-length VP2 gene induced higher Ab levels compared with the VP2 DNA vaccine without the HSP. It induced a mixed T helper 1- and T helper 2-like response as well as provided complete protection in a "DNA prime-protein boost" approach. ${ }^{99}$

\section{Mucosal vaccine delivery approaches as a way to enhance immunity}

Another approach to improve vaccine efficacy is to optimize the delivery of candidate vaccines by targeting specific immunological compartments, for example, antigen-presenting cells. Microparticle (MP) and nanoparticle delivery systems, particularly those made from biodegradable polymers such as poly(lactic-co-glycolic acid) (PLGA) and chitosan have been tested for mucosal delivery of poultry vaccines. ${ }^{97}$ Antigen delivery by this system has several advantages including preventing vaccine degradation by mucosal enzymes and a slow controlled antigen release to avoid frequent boosting. ${ }^{103,104}$ Targeted delivery and increased antigen uptake by antigenpresenting cells are other benefits. ${ }^{105}$ Mucosal immunization of chickens with PLGA MPs with an adsorbed IBDV DNA vaccine in conjunction with plasmids encoding chicken IL-2 or CpG oligodeoxynucleotide adsorbed onto different PLGA MPs induced a detectable T-cell response and protection against challenge. ${ }^{97}$ In addition, bacterial vectors including Salmonella and E. coli were used for the delivery of IBDV DNA vaccines through mucosal surfaces. ${ }^{106,107}$ In this case, the recombinant plasmid pCI-VP2/4/3 was transformed by electroporation into an attenuated Salmonella Typhimurium. Oral immunization of chickens with transformed bacteria elicited $\mathrm{Ab}$ responses offering approximately $73 \%$ protection against virulent IBDV challenge. ${ }^{106}$

\section{Reverse genetics and vaccinology}

The introduction of vaccines targeting reassortant subsets of circulating IBDVs may be necessary in future IBDV control strategies. Different reverse genetic systems for IBDV have been described, which can be used for better IBDV characterization and for IBDV vaccine development. ${ }^{108,109} \mathrm{~A}$ modified IBDV that contained an authentic $3^{\prime}$ RNA sequence generated by cis-acting hepatitis delta virus ribozyme was less pathogenic to the BF compared with a cell line-adapted variant $\mathrm{E}$ IBDV strain, but induced higher $\mathrm{Ab}$ responses as early as day 7 post infection. ${ }^{10}$ The risk of reversion to virulence of the genetically modified viruses may exist. ${ }^{11}$

\section{Conclusion and future perspectives}

Prevention of IBDV-related losses associated with immunosuppression and secondary infections will continue to be a specific focus in the field. ${ }^{112}$ Moreover, the identification and characterization of new emerging IBDV strains remains a major reason for the development of new vaccination strategies. In this regard, new sequencing technologies and bioinformatics will be used in the future to understand IBDV epidemiology and possibly predict the distribution of certain strains in the field.

It is suggested that the progression of an infection within a host will determine the ability of a pathogen to transmit to new hosts and to maintain itself in the population, ${ }^{113}$ therefore, additional understanding of IBDV pathogenesis and its interactions with the innate immune system is still required to provide the basis for improved prophylactic strategies. ${ }^{114}$ 
New technologies including transcriptomics and metabolomics may help to elucidate these aspects further.

Vectored IBD vaccines as well as immune complex vaccines have been licensed in recent years to overcome some of the problems related to classical vaccines. DNA vaccines have not been introduced to the field mainly due to variable or insufficient protection, especially after their mucosal delivery; the method of choice for IBDV-field vaccination. Therefore, efforts will continue to improve alternative vaccination strategies by testing new delivery systems and/or adjuvants to stimulate innate and acquired immunity. In addition to traditional adjuvants, other innovative strategies improving vaccine-induced immunity are under development, including inhibitors of metabolic pathways, modulators of baseline inflammation levels, monoclonal Abs targeting checkpoint inhibitors, and compounds depleting regulatory cells (reviewed by De Gregorio ${ }^{115}$ ). Possibly single-cycle replication incompetent and nontransmissible vector vaccines will gain more importance to overcome the risk of reversion to virulence of classical attenuated vaccine strains. ${ }^{116}$

New alternative prophylactic strategies may be investigated further, including the use of recombinant $\mathrm{Abs}$, recombinant single chain variable fragment Abs, or nanobodies specific for vvIBDV. ${ }^{117,118}$ MicroRNAs targeting specific viral proteins may also provide protection against IBDV challenge. ${ }^{119}$

Recently, the roles of mechanistic/mammalian target of rapamycin (mTOR), an intracellular regulator of innate and adaptive immunity, for controlling viral infections have been described. By regulating the autophagy machinery, mTOR leads in the generation of significant amounts of peptide epitopes by delivering antigens to the autophagosomes. These major histocompatibility complex class II antigens derived from intracellular sources may be presented by dendritic cells and cross-prime $\mathrm{CD}^{+} \mathrm{T}$-cells (reviewed by Puleston and Simon ${ }^{120}$ ). In IBDV infection, the interaction of VP2 protein with an avibirnavirusbinding receptor induces autophagy in an AKT-mTOR dependent pathway. ${ }^{121}$ Therefore, targeting autophagy may have promising implication in IBDV intervention strategy.

\section{Disclosure}

The authors report no conflicts of interest in this work.

\section{References}

1. Ramirez-Nieto G, Shivaprasad HL, Kim CH, et al. Adaptation of a mallard H5N2 low pathogenicity influenza virus in chickens with prior history of infection with infectious bursal disease virus. Avian Dis. 2010;54(1):513-521.

2. Müller H, Scholtissek C, Becht H. The genome of infectious bursal disease virus consists of two segments of double-stranded RNA. J Virol. 1979;31(3):584-589.
3. Khatri M, Sharma JM. Modulation of macrophages by infectious bursal disease virus. Cytogenet Genome Res. 2007;117(1-4):388-393.

4. Mahgoub HA, Bailey M, Kaiser P. An overview of infectious bursal disease. Arch Virol. 2012;157(11):2047-2057.

5. Luo J, Zhang H, Teng M, et al. Surface IgM on DT40 cells may be a component of the putative receptor complex responsible for the binding of infectious bursal disease virus. Avian Pathol. 2010;39(5):359-365.

6. Lin TW, Lo CW, Lai SY, et al. Chicken heat shock protein 90 is a component of the putative cellular receptor complex of infectious bursal disease virus. J Virol. 2007;81(16):8730-8741.

7. Delgui L, Oña A, Gutiérrez S, et al. The capsid protein of infectious bursal disease virus contains a functional alpha 4 beta 1 integrin ligand motif. Virology. 2009;386(2):360-372.

8. Yip CW, Hon CC, Zeng F, Leung FC. Cell culture-adapted IBDV uses endocytosis for entry in DF-1 chicken embryonic fibroblasts. Virus Res. 2012;165(1):9-16.

9. Käufer I, Weiss E. Significance of bursa of Fabricius as target organ in infectious bursal disease of chickens. Infect Immun. 1980;27(2): 364-367.

10. Cosgrove. An apparently new disease of chickens: avian nephrosis. Avian Dis. 1962;6(3):385-389.

11. Jackwood DJ, Sommer-Wagner S. Genetic characteristics of infectious bursal disease viruses from four continents. Virology. 2007;365(2): 369-375.

12. Jackwood DJ, Sommer SE. Identification of infectious bursal disease virus quasispecies in commercial vaccines and field isolates of this double-stranded RNA virus. Virology. 2002;304(1):105-113.

13. Birghan C, Mundt E, Gorbalenya AE. A non-canonical lon proteinase lacking the ATPase domain employs the ser-Lys catalytic dyad to exercise broad control over the life cycle of a double-stranded RNA virus. EMBO J. 2000;19(1):114-123.

14. Peters MA, Lin TL, Wu CC. Infectious bursal disease virus polyprotein expression arrests growth and mitogenic stimulation of B lymphocytes. Arch Virol. 2004;149(12):2413-2426.

15. Fahey KJ, Erny K, Crooks J. A conformational immunogen on VP-2 of infectious bursal disease virus that induces virus-neutralizing antibodies that passively protect chickens. J Gen Virol. 1989;70(6):1473-1481.

16. Lombardo E, Maraver A, Espinosa I, Fernández-Arias A, Rodriguez JF. VP5, the nonstructural polypeptide of infectious bursal disease virus, accumulates within the host plasma membrane and induces cell lysis. Virology. 2000;277(2):345-357.

17. Coulibaly F, Chevalier C, Gutsche I, et al. The birnavirus crystal structure reveals structural relationships among icosahedral viruses. Cell. 2005;120(6):761-772.

18. Schnitzler D, Bernstein F, Müller H, Becht H. The genetic basis for the antigenicity of the VP2 protein of the infectious bursal disease virus. J Gen Virol. 1993;74(8):1563-1571.

19. Coulibaly F, Chevalier C, Delmas B, Rey FA. Crystal structure of an Aquabirnavirus particle: insights into antigenic diversity and virulence determinism. J Virol. 2010;84(4):1792-1799.

20. Letzel T, Coulibaly F, Rey FA, et al. Molecular and structural bases for the antigenicity of VP2 of infectious bursal disease virus. $J$ Virol. 2007;81(23):12827-12835.

21. Müller H, Nitschke R. The two segments of the infectious bursal disease virus genome are circularized by a $90,000-D a$ protein. Virology. 1987;159(1):174-177.

22. Pan J, Vakharia VN, Tao YJ. The structure of a birnavirus polymerase reveals a distinct active site topology. Proc Natl Acad Sci U S A. 2007; 104(18):7385-7390.

23. Chettle N, Stuart JC, Wyeth PJ. Outbreak of virulent infectious bursal disease in East Anglia. Vet Rec. 1989;125(10):271-272.

24. Stoute ST, Jackwood DJ, Sommer-Wagner SE, et al. The diagnosis of very virulent infectious bursal disease in California pullets. Avian Dis. 2009;53(2):321-326.

25. Bayliss CD, Spies U, Shaw K, et al. A comparison of the sequences of segment $\mathrm{A}$ of four infectious bursal disease virus strains and identification of a variable region in VP2. J Gen Virol. 1990;71(6):1303-1312. 
26. Dormitorio TV, Giambrone JJ, Duck LW. Sequence comparisons of the variable VP2 region of eight infectious bursal disease virus isolates. Avian Dis. 1997; 41(1):36-44.

27. Durairaj V, Sellers HS, Linnemann EG, Icard AH, Mundt E. Investigation of the antigenic evolution of field isolates using the reverse genetics system of infectious bursal disease virus (IBDV). Arch Virol. 2011;156(10): 1717-1728.

28. Jackwood DJ, Sommer-Wagner SE. Amino acids contributing to antigenic drift in the infectious bursal disease Birnavirus (IBDV). Virology. 2011;409(1):33-37.

29. Kasanga CJ, Yamaguchi T, Wambura PN, Maeda-Machang'u AD, Ohya K, Fukushi H. Molecular characterization of infectious bursal disease virus (IBDV): diversity of very virulent IBDV in Tanzania. Arch Virol. 2007;152(4):783-790.

30. Mundt E. Tissue culture infectivity of different strains of infectious bursal disease virus is determined by distinct amino acids in VP2. J Gen Virol. 1999;80(8):2067-2076.

31. Jackwood DJ, Sreedevi B, LeFever LJ, Sommer-Wagner SE. Studies on naturally occurring infectious bursal disease viruses suggest that a single amino acid substitution at position 253 in VP2 increases pathogenicity. Virology. 2008;377(1):110-116.

32. He X, Xiong Z, Yang L, Guan D, Yang X, Wei P. Molecular epidemiology studies on partial sequences of both genome segments reveal that reassortant infectious bursal disease viruses were dominantly prevalent in southern China during 2000-2012. Arch Virol. 2014;159(12):3279-3292.

33. Negash T, Gelaye E, Petersen H, Grummer B, Rautenschlein S. Molecular evidence of very virulent infectious bursal disease viruses in chickens in Ethiopia. Avian Dis. 2012;56(3):605-610.

34. Jackwood DJ. Molecular epidemiologic evidence of homologous recombination in infectious bursal disease viruses. Avian Dis. 2012;56(3):574-577.

35. Vukea PR, Willows-Munro S, Horner RF, Coetzer TH. Phylogenetic analysis of the polyprotein coding region of an infectious South African bursal disease virus (IBDV) strain. Infect Genet Evol. 2014;21:279-286.

36. Cortey M, Bertran K, Toskano J, Majó N, Dolz R. Phylogeographic distribution of very virulent infectious bursal disease virus isolates in the Iberian Peninsula. Avian Pathol. 2012;41(3):277-284.

37. Silva FMF, Vidigal PMP, Myrrha LW, Fietto JL, Silva A Jr, Almeida MR. Tracking the molecular epidemiology of Brazilian infectious bursal disease virus (IBDV) isolates. Infect Genet Evol. 2013;13:18-26.

38. Li K, Courtillon C, Guionie O, et al. Genetic, antigenic and pathogenic characterization of four infectious bursal disease virus isolates from China suggests continued evolution of very virulent viruses. Infect Genet Evol. 2015;30:120-127.

39. Jackwood DJ, Stoute ST. Molecular evidence for a geographically restricted population of infectious bursal disease viruses. Avian Dis. 2013;57(1):57-64.

40. Gelb J, Jackwood DJ, Mundt E, et al. Characterization of infectious bursal disease viruses isolated in 2007 from Delmarva commercial broiler chickens. Avian Dis. 2012;56(1):82-89.

41. Hernández M, Tomás G, Marandino A, et al. Genetic characterization of South American infectious bursal disease virus reveals the existence of a distinct worldwide-spread genetic lineage. Avian Pathol. 2015;44(3): 212-221.

42. Hon CC, Lam TT, Yip CW, et al. Phylogenetic evidence for homologous recombination within the family Birnaviridae. J Gen Virol. 2008;89(12): 3156-3164.

43. Garriga D, Querol-Audí J, Abaitua F, et al. The 2.6-Angstrom structure of infectious bursal disease virus-derived $\mathrm{T}=1$ particles reveals new stabilizing elements of the virus capsid. J Virol. 2006;80(14):6895-6905.

44. Hon CC, Lam TY, Drummond A, et al. Phylogenetic analysis reveals a correlation between the expansion of very virulent infectious bursal disease virus and reassortment of its genome segment B. $J$ Virol. 2006;80(17):8503-8509.

45. Le Nouën C, Rivallan G, Toquin D, Eterradossi N. Significance of the genetic relationships deduced from partial nucleotide sequencing of infectious bursal disease virus genome segments A or B. Arch Virol. 2005;150(2):313-325.
46. Yamaguchi T, Ogawa M, Miyoshi M, Inoshima Y, Fukushi H, Hirai K. Sequence and phylogenetic analyses of highly virulent infectious bursal disease virus. Arch Virol. 1997;142(7):1441-1458.

47. Xia RX, Wang HY, Huang GM, Zhang MF. Sequence and phylogenetic analysis of a Chinese very virulent infectious bursal disease virus. Arch Virol. 2008;153(9):1725-1729.

48. Lu Z, Zhang L, Wang N, et al. Naturally occurring reassortant infectious bursal disease virus in northern China. Virus Res. 2015;203:92-95.

49. Pitesky M, Cataline K, Crossley B, et al. Historical, spatial, temporal, and time-space epidemiology of very virulent infectious bursal disease in California: a retrospective study 2008-2011. Avian Dis. 2013;57(1):76-82.

50. He X, Wei P, Yang X, Guan D, Wang G, Qin A. Molecular epidemiology of infectious bursal disease viruses isolated from Southern China during the years 2000-2010. Virus Genes. 2012;45(2):246-255.

51. Alfonso-Morales A, Rios L, Martínez-Pérez O, et al. Evaluation of a phylogenetic marker based on genomic segment $\mathrm{B}$ of infectious bursal disease virus: facilitating a feasible incorporation of this segment to the molecular epidemiology studies for this viral agent. PLoS One. 2015;10(5):e0125853.

52. Liu M, Vakharia VN. VP1 protein of infectious bursal disease virus modulates the virulence in vivo. Virology. 2004;330(1):62-73.

53. Boot HJ, Hoekman AJW, Gielkens ALJ. The enhanced virulence of very virulent infectious bursal disease virus is partly determined by its B-segment. Arch Virol. 2005;150(1):137-144.

54. Le Nouën C, Rivallan G, Toquin D, et al. Very virulent infectious bursal disease virus: reduced pathogenicity in a rare natural segmentB-reassorted isolate. J Gen Virol. 2006;87(1):209-216.

55. Le Nouën C, Toquin D, Müller H, et al. Different domains of the RNA polymerase of infectious bursal disease virus contribute to virulence. PLoS One. 2012(1); 7:e28064.

56. Yu F, Qi X, Yuwen Y, et al. Molecular characteristics of segment B of seven very virulent infectious bursal disease viruses isolated in China. Virus Genes. 2010;41(2):246-249.

57. Jackwood DJ, Crossley BM, Stoute ST, Sommer-Wagner S, Woolcock PR, Charlton BR. Diversity of genome segment B from infectious bursal disease viruses in the United States. Avian Dis. 2012;56(1):165-172.

58. Gao L, Li K, Qi X, et al. Triplet amino acids located at positions 145/146/147 of the RNA polymerase of very virulent infectious bursal disease virus contribute to viral virulence. J Gen Virol. 2014;95(4):888-897.

59. Yu F, Ren X, Wang Y, et al. A single amino acid V4I substitution in VP1 attenuates virulence of very virulent infectious bursal disease virus (vvIBDV) in SPF chickens and increases replication in CEF cells. Virology. 2013;440(2):204-209.

60. Doyle SL, O'Neill L a J. Toll-like receptors: from the discovery of NF- $\mathrm{\kappa B}$ to new insights into transcriptional regulations in innate immunity. Biochem Pharmacol. 2006;72(9):1102-1113.

61. Kogut MH, Iqbal M, He H, Philbin V, Kaiser P, Smith A. Expression and function of Toll-like receptors in chicken heterophils. Dev Comp Immunol. 2005;29(9):791-807.

62. Smith J, Sadeyen JR, Butter C, Kaiser P, Burt DW. Analysis of the early immune response to infection by infectious bursal disease virus in chickens differing in their resistance to the disease. $J$ Virol. 2015;89(5):2469-2482.

63. Lee CC, Kim B-S, Wu CC, Lin TL. Bursal transcriptome of chickens protected by DNA vaccination versus those challenged with infectious bursal disease virus. Arch Virol. 2015;160(1):69-80.

64. Ruby T, Whittaker C, Withers DR, et al. Transcriptional profiling reveals a possible role for the timing of the inflammatory response in determining susceptibility to a viral infection. J Virol. 2006;80(18):9207-9216.

65. Rauf A, Khatri M, Murgia MV, Jung K, Saif YM. Differential modulation of cytokine, chemokine and Toll like receptor expression in chickens infected with classical and variant infectious bursal disease virus. Vet Res. 2011;42:85.

66. Lee CC, Wu CC, Lin TL. Chicken melanoma differentiation-associated gene 5 (MDA5) recognizes infectious bursal disease virus infection and triggers MDA5-related innate immunity. Arch Virol. 2014;159(7): 1671-1686. 
67. Khatri M, Sharma JM. Infectious bursal disease virus infection induces macrophage activation via $\mathrm{p} 38$ MAPK and NF-kappaB pathways. Virus Res. 2006;118(1-2):70-77.

68. Khatri M, Palmquist JM, Cha RM, Sharma JM. Infection and activation of bursal macrophages by virulent infectious bursal disease virus. Virus Res. 2005;113(1):44-50.

69. Rasoli M, Yeap SK, Tan SW, et al. Differential modulation of immune response and cytokine profiles in the bursae and spleen of chickens infected with very virulent infectious bursal disease virus. BMC Vet Res. 2015;11:75.

70. Khatri M, Sharma JM. Response of embryonic chicken lymphoid cells to infectious bursal disease virus. Vet Immunol Immunopathol. 2009;127(3-4):316-324.

71. Rauf A, Khatri M, Murgia MV, Saif YM. Expression of perforingranzyme pathway genes in the bursa of infectious bursal disease virus-infected chickens. Dev Comp Immunol. 2011;3(5)5:620-627.

72. Sharma JM, Lee LF. Effect of infectious bursal disease on natural killer cell activity and mitogenic response of chicken lymphoid cells: role of adherent cells in cellular immune suppression. Infect Immun. 1983;42(2):747-754.

73. Goossens KE, KarpalaAJ, RohringerA, WardA, BeanAG. Characterisation of chicken viperin. Mol Immunol. 2015;63(2):373-380.

74. Goossens KE, Karpala AJ, Ward A, Bean AG. Characterisation of chicken ZAP. Dev Comp Immunol. 2014;46(2):373-381.

75. Ouyang W, Wang Y, Du X, Liu HJ, Zhang HB. gga-miR-9* inhibits IFN production in antiviral innate immunity by targeting interferon regulatory factor 2 to promote IBDV replication. Vet Microbiol. 2015;178(1-2):41-49.

76. Ye C, Jia L, Sun Y, et al. Inhibition of antiviral innate immunity by birnavirus VP3 protein via blockage of viral double-stranded RNA binding to the host cytoplasmic RNA detector MDA5. J Virol. 2014;88(19):11154-11165.

77. Liang J, Yin Y, Qin T, Yang Q. Chicken bone marrow-derived dendritic cells maturation in response to infectious bursal disease virus. Vet Immunol Immunopathol. 2015;164(1-2):51-55.

78. Azad AA, Jagadish MN, Brown MA, Hudson PJ. Deletion mapping and expression in Escherichia coli of the large genomic segment of a birnavirus. Virology. 1987;161(1):145-152.

79. Müller H, Mundt E, Eterradossi N, Islam MR. Current status of vaccines against infectious bursal disease. Avian Pathol. 2012;41(2):133-139.

80. Van den Berg TP, Eterradossi N, Toquin D, Meulemans G. Infectious bursal disease (Gumboro disease). Rev Sci Tech. 2000;19(2):509-543.

81. Yamaguchi T, Setiyono A, Kobayashi M, Takigami S, Fukushi H, Hirai K. Infectious bursal disease live vaccines: changes in the virus population during serial passage in chickens and chicken embryo fibroblast cells. Avian Dis. 2000;44(2):284-290.

82. Rautenschlein S, Kraemer C, Vanmarcke J, Montiel E. Protective efficacy of intermediate and intermediate plus infectious bursal disease virus (IBDV) vaccines against very virulent IBDV in commercial broilers. Avian Dis. 2005;49(2):231-237.

83. Maas RA, Venema S, Oei HL, Pol JM, Claassen IJ, Huurne AA. Efficacy of inactivated infectious bursal disease (IBD) vaccines: comparison of serology with protection of progeny chickens against IBD virus strains of varying virulence. Avian Pathol. 2001;30(4):345-354.

84. Haddad EE, Whitfill CE, Avakian AP, et al. Efficacy of a novel infectious bursal disease virus immune complex vaccine in broiler chickens. Avian Dis. 1997;41(4):882-889.

85. Iván J, Velhner M, Ursu K, et al. Delayed vaccine virus replication in chickens vaccinated subcutaneously with an immune complex infectious bursal disease vaccine: quantification of vaccine virus by real-time polymerase chain reaction. Can J Vet Res. 2005;69(2):135-142.

86. Whitfill CE, Haddad EE, Ricks CA, et al. Determination of optimum formulation of a novel infectious bursal disease virus (IBDV) vaccine constructed by mixing bursal disease antibody with IBDV. Avian Dis. 1995;39(4):687-699.

87. Bublot M, Pritchard N, Le Gros FX, Goutebroze S. Use of a vectored vaccine against infectious bursal disease of chickens in the face of high-titred maternally derived antibody. J Comp Pathol. 2007;137(S1): S81-S84.
88. Le Gros FX, Dancer A, Giacomini C, et al. Field efficacy trial of a novel HVT-IBD vector vaccine for 1-day-old broilers. Vaccine. 2009;27(4): 592-596.

89. Chang HC, Lin TL, Wu CC. DNA-mediated vaccination against infectious bursal disease in chickens. Vaccine. 2001;20(3-4):328-335.

90. Hsieh MK, Wu CC, Lin TL. DNA-mediated vaccination conferring protection against infectious bursal disease in broiler chickens in the presence of maternal antibody. Vaccine. 2010;28(23): 3936-3943.

91. Pitcovski J, Gutter B, Gallili G, et al. Development and large-scale use of recombinant VP2 vaccine for the prevention of infectious bursal disease of chickens. Vaccine. 2003;21(32):4736-4743.

92. Rong J, Jiang T, Cheng T, et al. Large-scale manufacture and use of recombinant VP2 vaccine against infectious bursal disease in chickens. Vaccine. 2007;25(46):7900-7908.

93. Li K, Gao H, Gao L, et al. Adjuvant effects of interleukin-18 in DNA vaccination against infectious bursal disease virus in chickens. Vaccine. 2013;31(14):1799-1805.

94. Kumar S, Ahi YS, Salunkhe SS, et al. Effective protection by high efficiency bicistronic DNA vaccine against infectious bursal disease virus expressing VP2 protein and chicken IL-2. Vaccine. 2009;27(6): 864-869.

95. Su BS, Chiu HH, Lin CC, Shien JH, Yin HS, Lee LH. Adjuvant activity of chicken interleukin-12 co-administered with infectious bursal disease virus recombinant VP2 antigen in chickens. Vet Immunol Immunopathol. 2011;139(2-4):167-175.

96. Schijns VE, Weining KC, Nuijten P, Rijke EO, Staeheli P. Immunoadjuvant activities of $E$. coli- and plasmid-expressed recombinant chicken IFN-alpha/beta, IFN-gamma and IL-1beta in 1-day- and 3-week-old chickens. Vaccine. 2000;18(20):2147-2154.

97. Negash T, Liman M, Rautenschlein S. Mucosal application of cationic poly(D,L-lactide-co-glycolide) microparticles as carriers of DNA vaccine and adjuvants to protect chickens against infectious bursal disease. Vaccine. 2013;31(36):3656-3662.

98. Hung CM, Yeh CC, Chen HL, et al. Porcine lactoferrin administration enhances peripheral lymphocyte proliferation and assists infectious bursal disease vaccination in native chickens. Vaccine. 2010;28(16): 2895-2902.

99. Maity HK, Dey S, Mohan CM, Khulape SA, Pathak DC, Vakharia VN. Protective efficacy of a DNA vaccine construct encoding the VP2 gene of infectious bursal disease and a truncated HSP70 of Mycobacterium tuberculosis in chickens. Vaccine. 2015;33(8):1033-1039.

100. Zhang H, Yang X, Xie Q, et al. The potent adjuvant effects of chicken beta-defensin-1 when genetically fused with infectious bursal disease virus VP2 gene. Vet Immunol Immunopathol. 2010;136(1-2):92-97.

101. Wang X, Jiang P, Deen S, Wu J, Liu X, Xu J. Efficacy of DNA vaccines against infectious bursal disease virus in chickens enhanced by coadministration with CpG oligodeoxynucleotide. Avian Dis. 2003;47(4): 1305-1312.

102. Mahmood MS, Siddique M, Hussain I, Khan A, Mansoor MK. Protection capability of recombinant plasmid DNA vaccine containing VP2 gene of very virulent infectious bursal disease virus in chickens adjuvanted with CpG oligodeoxynucleotide. Vaccine. 2006;24(22): 4838-4846.

103. Jones DH, Clegg JC, Farrar GH. Oral delivery of micro-encapsulated DNA vaccines. Dev Biol Stand. 1998;92:149-155.

104. Singh M, McGee JP, Li XM, et al. Biodegradable microparticles with an entrapped branched octameric peptide as a controlled-release HIV-1 vaccine. J Pharm Sci. 1997;86(11):1229-1233.

105. Kazzaz J, Singh M, Ugozzoli M, Chesko J, Soenawan E, O’Hagan DT. Encapsulation of the immune potentiators MPL and RC529 in PLG microparticles enhances their potency. J Control Release. 2006;110(3): 566-573.

106. Mahmood MS, Hussain I, Siddique M, Akhtar M, Ali S. DNA vaccination with VP2 gene of very virulent infectious bursal disease virus (vvIBDV) delivered by transgenic E. coli DH5alpha given orally confers protective immune responses in chickens. Vaccine. 2007;25(44): 7629-7635. 
107. Li L, Fang W, Li J, Huang Y, Yu L. Oral DNA vaccination with the polyprotein gene of infectious bursal disease virus (IBDV) delivered by the attenuated Salmonella elicits protective immune responses in chickens. Vaccine. 2006;24(33-34):5919-5927.

108. Mundt E, Vakharia VN. Synthetic transcripts of double-stranded Birnavirus genome are infectious. Proc Natl Acad Sci U S A. 1996; 93(20):11131-11136.

109. Silva JVJ, Arenhart S, Santos HF, et al. Efficient assembly of fulllength infectious clone of Brazilian IBDV isolate by homologous recombination in yeast. Braz J Microbiol. 2014;45(4):1555-1563.

110. Mosley YYC, Wu CC, Lin TL. Infectious bursal disease virus rescued efficiently with $3^{\prime}$ authentic RNA sequence induces humoral immunity without bursal atrophy. Vaccine. 2013;31(4):704-710.

111. Raue R, Islam MR, Islam MN, et al. Reversion of molecularly engineered, partially attenuated, very virulent infectious bursal disease virus during infection of commercial chickens. Avian Pathol. 2004;33(2):181-189.

112. Hoerr FJ. Clinical aspects of immunosuppression in poultry. Avian Dis. 2010;54(1):2-15.

113. Handel A, Rohani P. Crossing the scale from within-host infection dynamics to between-host transmission fitness: a discussion of current assumptions and knowledge. Philos Trans R Soc Lond B Biol Sci. $2015 ; 370$.

114. Ingrao F, Rauw F, Lambrecht B, van den Berg T. Infectious bursal disease: a complex host-pathogen interaction. Dev Comp Immunol. 2013;41(3):429-438.

115. De Gregorio E. The path forward. Vaccine. 2015;33(S2):B60-B63.

116. Kalhoro NH, Veits J, Rautenschlein S, Zimmer G. A recombinant vesicular stomatitis virus replicon vaccine protects chickens from highly pathogenic avian influenza virus (H7N1). Vaccine. 2009;27(8):1174-1183.

117. Sapats SI, Trinidad L, Gould G, et al. Chicken recombinant antibodies specific for very virulent infectious bursal disease virus. Arch Virol. 2006;151(8):1551-1566.

118. Xu LM, Li TH, Zhou B, et al. scFv antibodies against infectious bursal disease virus isolated from a combinatorial antibody library by flow cytometry. Biotechnol Lett. 2014;36(5):1029-1035.

119. Wang Y, Sun H, Shen P, Zhang X, Xia X, Xia B. Effective inhibition of replication of infectious bursal disease virus by miRNAs delivered by vectors and targeting the VP2 gene. J Virol Methods. 2010;165(2): $127-132$

120. Puleston DJ, Simon AK. Autophagy in the immune system. Immunology. 2014;141(1):1-8.

121. Hu B, Zhang Y, Jia L, et al. Binding of the pathogen receptor HSP90AA1 to avibirnavirus VP2 induces autophagy by inactivating the AKT-MTOR pathway. Autophagy. 2015;11(3):503-515.

122. Villegas P, Hamoud M, Purvis LB, Perozo F. Infectious bursal disease subunit vaccination. Avian Dis. 2008;52(4):670-674.

123. Pradhan SN, Prince PR, Madhumathi J, Roy P, Narayanan RB, Antony U. Protective immune responses of recombinant VP2 subunit antigen of infectious bursal disease virus in chickens. Vet Immunol Immunopathol. 2012;148(3-4):293-301.

124. Wang Y, Fan H, Li Y, Shi ZL, Pan Y, Lu CP. Development of a multi-mimotope peptide as a vaccine immunogen for infectious bursal disease virus. Vaccine. 2007;25(22):4447-4455.

Veterinary Medicine: Research and Reports

\section{Publish your work in this journal}

Veterinary Medicine: Research and Reports is an international, peer-reviewed, open access journal publishing original research, case reports, editorials, reviews and commentaries on all areas of veterinary medicine. The manuscript management system is completely online and includes a very quick and fair peer-review system.
125. Wu H, Singh NK, Locy RD, Scissum-Gunn K, Giambrone JJ. Immunization of chickens with VP2 protein of infectious bursal disease virus expressed in Arabidopsis thaliana. Avian Dis. 2004;48(3): 663-668.

126. Wu J, Yu L, Li L, Hu J, Zhou J, Zhou X. Oral immunization with transgenic rice seeds expressing VP2 protein of infectious bursal disease virus induces protective immune responses in chickens. Plant Biotechnol J. 2007;5(5):570-578.

127. Chen $\mathrm{TH}, \mathrm{Chen} \mathrm{TH}, \mathrm{Hu} \mathrm{CC}$, et al. Induction of protective immunity in chickens immunized with plant-made chimeric Bamboo mosaic virus particles expressing very virulent Infectious bursal disease virus antigen. Virus Res. 2012;166(1-2):109-115.

128. Tang Y, Gong Y, Wang Y, et al. Chimaeric VP2 proteins from infectious bursal disease virus containing the N-terminal M2e of H9 subtype avian influenza virus induce neutralizing antibody responses to both viruses. Avian Pathol. 2013;42(3):260-267.

129. Wang Y, Ouyang W, Liu X, et al. Virus-like particles of hepatitis B virus core protein containing five mimotopes of infectious bursal disease virus (IBDV) protect chickens against IBDV. Vaccine. 2012; 30(12):2125-2130.

130. Tsukamoto K, Sato T, Saito S, et al. Dual-viral vector approach induced strong and long-lasting protective immunity against very virulent infectious bursal disease virus. Virology. 2000;269(2):257-267.

131. Tsukamoto K, Kojima C, Komori Y, Tanimura N, Mase M, Yamaguchi S. Protection of chickens against very virulent infectious bursal disease virus (IBDV) and Marek's disease virus (MDV) with a recombinant MDV expressing IBDV VP2. Virology. 1999;257(2): $352-362$.

132. Phenix K V, Wark K, Luke CJ, et al. Recombinant Semliki Forest virus vector exhibits potential for avian virus vaccine development. Vaccine. 2001;19(23-24):3116-3123.

133. Zanetti FA, Del Médico Zajac MP, Taboga OA, Calamante G. Evaluation of modified vaccinia virus Ankara expressing VP2 protein of infectious bursal disease virus as an immunogen in chickens. $J$ Vet Sci. 2012;13(2):199-201.

134. Francois A, Chevalier C, Delmas B, et al. Avian adenovirus CELO recombinants expressing VP2 of infectious bursal disease virus induce protection against bursal disease in chickens. Vaccine. 2004;22(17-18): 2351-2360.

135. Cao YC, Shi QC, Ma JY, Xie QM, Bi YZ. Vaccination against very virulent infectious bursal disease virus using recombinant T4 bacteriophage displaying viral protein VP2. Acta Biochim Biophys Sin (Shanghai). 2005;37(10):657-664.

136. Zanetti FA, Grand MDC, Mitarotonda RC, Taboga OA, Calamante G. Canarypox virus expressing infectious bursal disease VP2 protein as immunogen for chickens. Braz J Microbiol. 2014;45(1): 231-234.

137. Pradhan SN, Prince PR, Madhumathi J, et al. DNA vaccination with VP2 gene fragment confers protection against infectious bursal disease virus in chickens. Vet Microbiol. 2014;171(1-2):13-22.

138. Gao H, Li K, Gao L, et al. DNA prime-protein boost vaccination enhances protective immunity against infectious bursal disease virus in chickens. Vet Microbiol. 2013;164(1-2):9-17.
Visit http://www.dovepress.com/testimonials.php to read real quotes from published authors. 